\title{
Determinants of International Technology Transfer: an Empirical Analysis of the Enterprise Europe Network
}

\author{
Carina Araújo', Aurora Teixeira²
}

\begin{abstract}
This paper explores the key factors that foster technology transfer within the triad university-industry-government in an international context, i.e., the Enterprise Europe Network (EEN). Based on 7I technological Partnership Agreements (PAs), estimation results indicate that PAs associated to partners that provide their collaborators with the appropriate training in technology transfer-related issues, present substantial past experience in international or technological projects, and participate in extensive networks, are those that achieve better performances in terms of international technology transfer. High levels of formal schooling per se are not a key determinant of international technology transfer; the critical factor is highly educated human resources who receive complementary training in technology transfer issues.
\end{abstract}

Keywords: international technology transfer; triple helix; enterprise europe network.

\footnotetext{
1,2 Faculdade de Economia do Porto, Rua Dr Roberto Frias, 4200-464, Porto, Portugal.

Phone: +35 I22557I I00; e-mail: ' I 1040024 I@fep.up.pt, ${ }^{2}$ ateixeira@fep.up.pt
} 


\section{Introduction}

Over the last few years, there has been a global move towards a knowledge-based economy (Arvanitis and Woerter, 2009; Lai, 20I I), in which knowledge and technology have become the most important resources (Lee, et al., 2007) for the endowment of companies and the growth of industries (Laroche and Amara, 20I I). Studies conducted in sociology, economics and management have confirmed the central role of technology in changes to productivity and economic development (Reddy and Zhao, 1990). Simultaneously, strategic theorists have recommended a competitive strategy based on the rise of technology as a competitive force (Reddy and Zhao, 1990).

Intensive global competition and fast technological development (Santoro and Gopalakrishnan, 2000) have created new challenges for organizations and they are often faced with a lack of resources and time to keep a leading edge (Sherwood and Covin, 2008). This impels them to go beyond their boundaries and look for external sources of knowledge (Sherwood and Covin, 2008; Arvanitis and Woerter, 2009).

This new technological setting has given rise to new linkages between industry (suppliers, customers, competitors) and public organizations, such as research institutions (Arvanitis and Woerter, 2009) and universities (Sherwood and Covin, 2008; Lai, 20II). Universities have become aware of the commercial value of their research and they are now focused on the 'capitalization of knowledge' (Etzkowitz, 1998). Likewise, industry has recognized the positive impact of knowledge produced in universities (Laroche and Amara, 20II) on their innovation and economic performance (Arvanitis and Woerter, 2009).

Increasingly, science and business institutions espouse strategies to improve their performance through cooperation with other organizations (Arvanitis and Woerter, 2009). In such a scenario, technology transfer is of major importance (Duan, et al., 20I0; Lai, 20I I). The process by which technology is acquired from external sources has drawn the attention of a large number of researchers in recent years (Teixeira and Mota, 20I2).

Several studies (e.g., Reddy and Zhao, 1990; Sung, et al., 2003; Gopalakrishnan and Santoro, 2004; Santoro and Bierly, 2006) analyze the key factors of technology transfer between university and industry (namely, absorptive capacity, human capital, trust, social connectedness, prior experience with partnerships, international experience) and the importance of intermediary organizations. However, such literature usually focuses on technology transfer within a sector, region or country, neglecting its international dimension. Moreover, it has disregarded the key factors that sustain the activity of technology transfer intermediaries at international level.
Thus, the present study analyzes international technology transfer within a Triple Helix collaboration with the objective of understanding the key factors that boost technology transfer in this context, and outlines the main features of the entities involved in cases of successful technology transfer. To achieve this objective, we conceptualize the Triple Helix matrix focusing on the European project, Enterprise Europe Network (EEN). Technology transfer in the EEN is closely followed by the partners and can be traced through the partnership agreements (PAs) which are signed by the EEN partners and the beneficiaries involved in the transfer.

Based on direct questionnaires to EEN partners, we analyse their involvement as well as the key features of the owner/ originator, intermediary and receptor of the technology.Additionally, the determinants of such transfers can be identified through the analysis of the impact of the technology transfer on the organization.

This paper is organized as follows. The next section provides a review of the literature regarding technology transfer within a triple helix framework. Next, in Section 3, the methodological approach and data gathering procedures are presented. The results are analyzed and discussed in Section 4. Finally, the Conclusions summarizes the main results and puts forward the main limitations and future paths for research.

\section{Key factors of international technology transfer and main hypothesis to be tested}

In an international context, technology transfer can flow through numerous channels (Glass and Saggi, 2002). Categorizing the literature on technology, its process of transfer and its international scope, would be unfruitful (Bozeman, 2000) but general characteristics can be traced. In a simple definition, technology transfer can be described as the process through which organizations acquire technology from an external source (Bessant and Rush, 1993; Cumming and Teng, 2003).

The technology transfer process tends to be stimulated if certain key facilitators - e.g., social connectedness, trust, prior experience - are present (Santoro and Bierly, 2006). These facilitators are closely related with: (I) hybrid organizational characteristics (2) clients' characteristics and (3) relations between the hybrid organizations and their clients within a technology transfer process. Among the many determinants of technology transfer proposed, some stand out: absorptive capacity, human capital, trust, social connectedness, prior experience with partnerships, international experience. Within a triple helix framework, technology transfer depends on industry characteristics, EEN characteristics and the industry perception of the EEN. 


\section{Human capital and absorptive capacity}

The determinants of successful technology transfer are closely related with the actors involved. In a transfer process the capacity to absorb and re-use that technology can either enhance or undermine the success of the transfer (Duan, et al., 20l0).According to the empirical evidence, the adoption of a technology can be facilitated by certain skills rooted in the human capital of a closed economy or a country promoting the acceptance of new or external technologies (Keller, 2004). In other words, human capital facilitates technology transfer between and beyond national boundaries (Keller, 2004; Kneller, et al., 20I0).

Since the EEN highlights the importance of their human resources, we believe that the skills of the EEN consultants are decisive during an international technology transfer.

$\mathrm{HI}$ : International technology transfer depends directly on the organizations' human capital endowment.

Human capital is frequently included in the absorptive capacity (Kneller, et al., 2010). Although the term absorptive capacity was presented by Cohen and Levinthen (1990), the idea had been mentioned previously by Madeuf (1983). In his work about international technology transfer and international technology payments, the author states that a transfer can only be successful when the recipient is able to use, reproduce and even improve the technology transfer on its own. Cohen and Levinthen (1990) define absorptive capacity as the ability to recognize the value of new external information and successfully adopt, assimilate and exploit it. It can be applied not only to companies but also to countries (Keller, 2004) and, in equal circumstances of access, determines the ability of a company or country to benefit from the technology (Kneller, et al., 20I0). Not surprisingly, absorptive capacity is referred to by several authors as a key determinant in the transfer of technology (Cohen and Levinthen, 1990; Keller, 2004; Gopalakrishnan and Santoro, 2004; Santoro and Bierly, 2006; Kneller, et al., 2010).

Despite the literature's focus on the relationship between technology transfer and capacities and the actors involved in a bilateral perspective, the same connection between the actors of the Triple Helix is also expectable. In the context of our analysis, absorptive capacity will not only determine the capacity of a EEN partner to identify the value of a technological cooperation for its clients but also the capacity of its clients to internalize external knowledge and take advantage of it. Therefore, it is expected that a successful technology transfer mediated by the EEN depends on the absorptive capacity of the stakeholders.
$\mathrm{H} 2$ : The success of an international technology transfer involving a technology broker depends directly on the absorptive capacity of the stakeholders.

\section{Connectedness and networking dynamics}

Also related with the actors involved in technology transfers, and as important as absorptive capacity, is connectedness between the partners. According to several authors (Gopalakrishnan and Santoro, 2004; Santoro and Bierly, 2006; Duan, et al., 20I0; Laroche and Amara, 20II), connectedness between partners plays a crucial role in technology transfers.

Environments that foster interpersonal relationships can be conductors in the knowledge flow (Santoro and Bierly, 2006), since acquaintances facilitate the working arrangements between partners (Duan, et al., 20l0). As noted by Sherwood and Covin (2008), familiarity among partners can foster routines of knowledge-sharing, which leads to the mutual understanding of procedures and practices and, consequently, promotes the acquisition of technology.

The strength of these innovative capabilities was also referred to as technological relatedness by Santoro and $\mathrm{Bi}$ erly (2006). Due to limited resources and expertise, companies frequently collaborate with university research centres (URCs) with the aim of accessing new technologies (Santoro and Bierly, 2006). The overlap between access to knowledge access and the strength of the technological base is, according to the authors, one of the facilitators of knowledge transfer. Similarly, the same connectedness between the actors of the Triple Helix is also expected. Indeed, Gkikas (20II) refers to the importance of networking to the innovativeness of a firm. Based on his research in other studies, he concludes that the innovativeness of a firm is positively correlated with collaboration with other entities, more specifically, among Triple Helix actors.

$\mathrm{H} 3$ : International technology transfer is facilitated if network connectedness is encouraged.

\section{Trust and common objectives}

Trust is one of the most important elements in an interorganizational partnership (Santoro and Bierly, 2006) and a determinant for its success (Sherwood and Covin, 2008). Existing not only between individuals, but also between organizations (Sherwood and Covin, 2008), trust can be described as a mutual belief that the other part will act in view of compatible interests rather than opportunistically (Gopalakrishnan and Santoro, 2004; Santoro and Bierly, 2006). Sherwood and Covin (2008) confirmed in their study that the success of knowledge acquisition in university- 
industry alliances depends on routines of knowledge-sharing built on legitimate trust between the sending and the receiving partner.

In an organizational approach, apart from the organization's history and culture, Gopalakrishnan and Santoro (2004) also related the likelihood of establishing trust relationships between a company and a university partner with their shared values.According to the authors, companies will tend to trust a university partner if they believe that their strategic objectives will be better achieved by integrating the expertise of the university partner. In fact, the company's willingness to trust relies on its belief in the university partner's expertise and in its availability to share it and to jointly accomplish the company's objectives (Gopalakrishnan and Santoro, 2004; Santoro and Bierly, 2006). Furthermore, when trust is built between a company and a university partner, confidence regarding abilities and behaviour also increases, as well as the willingness to share ideas and goals (Gopalakrishnan and Santoro, 2004; Santoro and Bierly, 2006). Apart from enabling open communication and knowledge transfer between companies and university research centres (Gopalakrishnan and Santoro, 2004; Santoro and Bierly, 2006), as well as the receiving and sending organizations (Sherwood and Covin, 2008), the same is expected between the units of analysis in this paper. Trust between a hybrid organization and its clients is expected to foster the success of international technology transfer.

$\mathrm{H} 4$ :The success of international technology transfer is positively related with the trust relationship between the technology sender/ recipient and the trilateral network.

\section{Prior experience in international or technological partnerships}

Prior experience in partnerships can be critical in technology transfer (Santoro and Bierly, 2006; Sherwood and Covin, 2008; Arvanitis and Woerter, 2009). Similarly, companies with international experience are more prone to effectively transfer technology at international level (Reddy and Zhao, 1990). Companies with prior experience in partnerships learn from their past success and failures, building relevant knowledge that allows them to more rapidly understand collaboration opportunities, to appropriately manage the alliance and to benefit from it (Santoro and Bierly, 2006; Sherwood and Covin, 2008; Arvanitis and Woerter, 2009). Thus, prior experience can suggest a propensity to establish successful alliances, including partnerships for the transfer of technology (Santoro and Bierly, 2006).
From the perspective of the university-industry collaboration, the company's prior experience in working with a university can be decisive in a process of technology transfer (Santoro and Bierly, 2006).

H5: International technology transfer depends on the prior experience of the organization in international or technological partnerships.

\section{Control Variables: size and sector}

There are different conclusions regarding the influence of an organization's size and sector in technology transfer activities (Gopalakrishnan and Santoro, 2004; Santoro and Bierly, 2006). Prior studies indicate that university-industry relationships are highly sector specific (Santoro and Bierly, 2006) and size defines the partners' interface mechanisms (Sherwood and Covin, 2008).

\section{Methodology}

The Enterprise Europe Network (EEN) is part of the Competitiveness and Innovation Framework Programme (CIP), which is a European Commission programme aimed at fostering the competitiveness of European companies through innovation and eco-innovation activities. The EEN was launch on Istjanuary 2008 with approximately 567 partner organizations located in 44 countries, including EU 17 and neighbouring countries (EC- CIP, 2008). The mission of the EEN is to facilitate the access of small and medium companies to the EU Single Market, supporting business and innovation at local level.

The EEN project was selected as the empirical basis for our research framework because: (I) cross-border cooperation is at the root of the network; (2) as a whole, partners cover the three spheres of the helix, i.e., universities, the private sector and public/governmental entities; (3) to achieve their goals partners have to establish connections amongst themselves, which means the creation of links between entities located in different countries and with different key roles.

In 2012, the network had 589 member organizations in 49 European and neighbouring countries. Beyond the EU 27 countries, the network has extended its coverage to European Economic Area countries and other economic areas such as the United States of America, Russia, South Korea, Japan and China. 
With regard to technology transfer, it should be mentioned that the EEN services are extending to universities and other research centres interested in establishing a technological partnership whether for development or commercialization. The support typically provided to technology transfer in the EEN is similar to the process exemplified in Figure I.

The client (a company, university and other research centre) with a technological offer or request contacts the local EEN partner, and a meeting is set up. According to the strategy outlined by the organization and the objectives established during the meeting, the best set of instruments will be used to find the right partner. Once found, a Partnership Agreement $(P A)$ is signed by the organizations involved and the EEN partners. The Partnership Agreement (PA) is an internal document with reference to the technology transferred, the organizations ('Client') and EEN partners involved.The technology transfer within the EEN might involve three sets of flows (between EENs clients): transfer between two companies; transfer between a company and a university/research centre; transfer between two universities/research centres.
The selection of the relevant variables was guided by the literature review on university-industry partnerships and technology transfer activities. The summary of the determinants of technology transfer proposed indifferent studies are described in Table I, as well as the proxies used.

The questionnaire sent to EEN partners had three groups of questions on general information, activities and technological partnership agreements. The questionnaire sent to EEN clients was formed by four parts on general information, relationship with the EEN, relationship within the Triple Helix, and technological partnership agreements. The questionnaires were personalized, and each Partnership Agreement (PA) was treated separately, so that the respondents received a questionnaire in which one group was related to each PA in which they were involved.

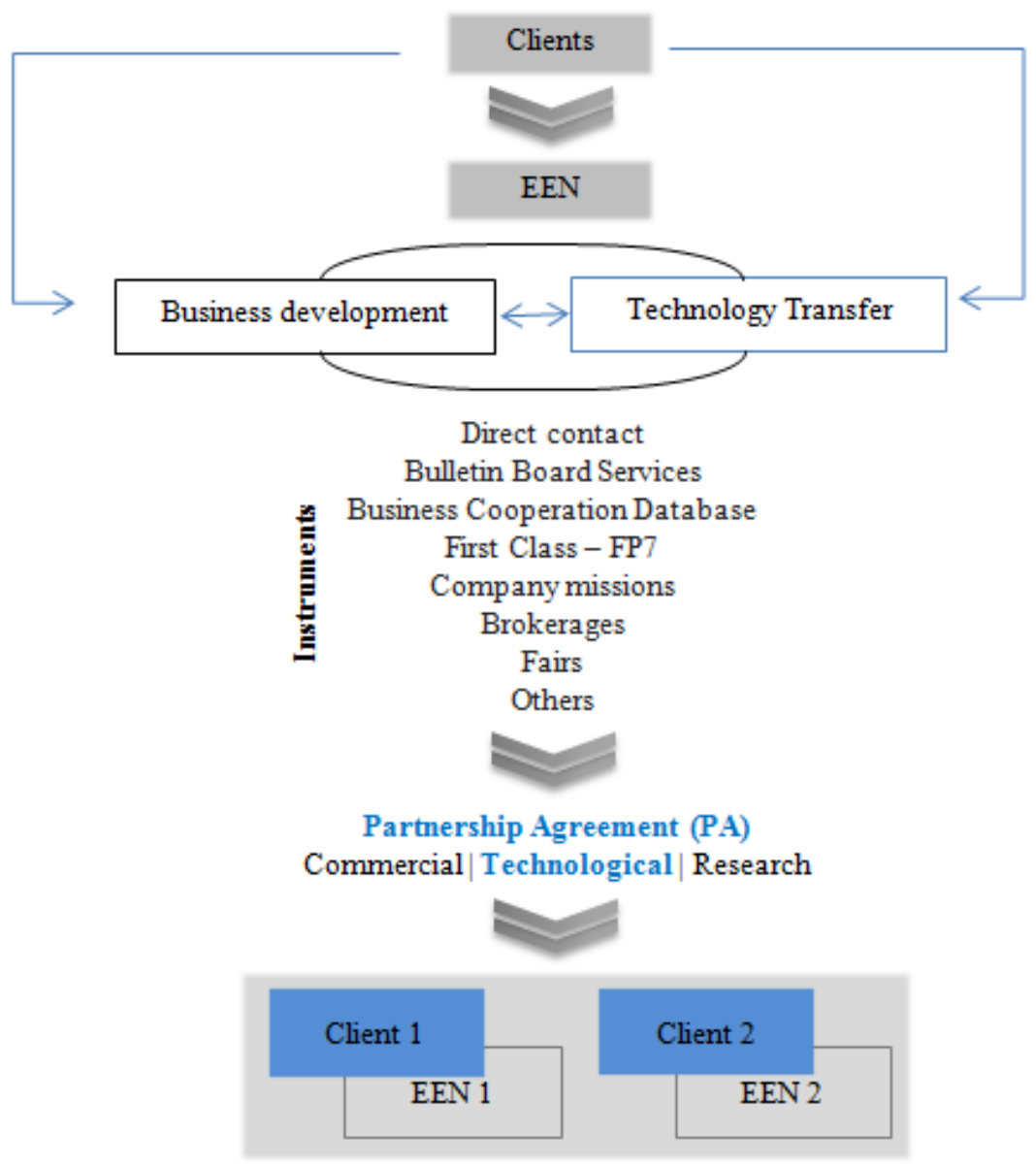

Figure I: A typical support process in the Enterprise Europe Network Source: Authors' compilation

ISSN: 07 I8-2724. (http://www.jotmi.org) 
Transfer technology between international partners is the dependent variable of this study. The transfer of technology is not just the flow between a sending and a receiving company. Its success depends on the effectiveness and control of the recipient to use, reproduce and even improve the technology (Madeuf, 1983). Although various approaches have been used (Cumming and Teng, 2003) in the attempt to define successful transfer as a variable, we have followed Madeuf's (1983) approach and assume that the impact on the recipient organization determines the success of the technology transfer.

With this in mind, we adapted Santoro and Bierly's (2006) measure of knowledge transfer from the university research centre to companies. To measure the successfulness of the international technology transfer, a seven-point Likert-type scale $(I=$ strongly disagree, $4=$ neither agree nor disagree, 7 = strongly agree) was used, and the EEN clients (that is, firms, universities or research centres) were questioned about the value and utility of the technology transfer to the organization. Depending on the function in the transfer, sender or receiver, the participants were asked to evaluate the degree of learning, assimilation and results arising from the PA involved. As mentioned previously, within the EEN, only technological transfers between international partners can be reported as a partnership agreement. Therefore, the PA in this study is, by definition, international. R\&D activities, workforce education and training are pointed out by numerous authors as the main indicators of a firm's absorptive capacity (Santoro and Bierly, 2006; Arvanitis and Woerter, 2009; Kneller, et al., 2010). Although the authors are consensual about the importance of R\&D, workforce and training, there is a lack of agreement regarding the proxies to be used to reflect the absorptive capacity of an organization. The educational achievement of the organizations' labour force (Arvanitis and Woerter, 2009), R\&D intensity (Kneller, et al., 2010) or training are some of the different proxies used to analyze the absorptive capacity of an organization.

Due the importance of the capabilities and skills of the EEN consultants in the network's strategy and activity (EC-EIP, 20I0), we compute the proxy for absorptive capacity of the EEN partners based on the education level of the consultancy staff and the average EEN budget invested in training activities in technology-related fields.
In the same way, the absorptive capacity of the EEN clients is measured by the education level of the employees involved in ITT and the average of the turnover invested in training activities in technology-related fields. In addition to these proxies, we follow Cohen and Levinthal's (1990) study, and measure the R\&D intensity of a firm by its share of investment in the company's sales revenue. This measure helps us to understand the client's technological capability and therefore its capacity to transfer technology.

As the unit of analysis of this paper is the international technology transfer involving a trilateral network, we want to understand whether the connectedness between those organizations and their clients is decisive to the success of the transfer. Hence, we follow the work of Santoro and Bierly (2006) to measure the interactions at the individual level of the partnership. To measure the networking dynamics between the EEN and its clients, we follow the Triple Helix metrics proposed by Gkikas (20I I).

With reference to the three years period, 2009-20II, the EEN partners were asked about the (I) number of technological offers (TO) and requests (TR) submitted; (2) number of expression of interest (EOI); and (3) the number of technological partnerships obtained. They were also queried about their opinion regarding their role within the client's strategy in accessing new ideas, and developing and transferring new technologies.

Additionally, EEN clients where asked how important the EEN is in accessing, building and transferring technology. Except for the overall number of TO/TR, EOls and technological PAs, connectedness and networking dynamics indicators were measured using a seven-point Likert-type scale $(I=$ strongly disagree, $4=$ neither agree nor disagree, $7=$ strongly agree).

As mentioned earlier, the EEN fosters a relationship of proximity between its consultants and its clients. For this reason, trust was measured by blending inter-organizational and interpersonal trust. To measure the client's trust in the EEN partner, we combined the work of Mayer, et al. (1995) on factors of trustworthiness, with the work of Zaheer, et al. (1998) regarding inter-organizational trust on performance. These combined measures required the EEN clients to assess their trust in the EEN partner in terms of ability, goodwill and integrity. However, not all of the Zaheer, et al.'s (1998) items were applicable to our research. As in the aforementioned authors' work, the items measuring interorganizational trust were closely related with a supply-costumer relation. Thus, we had to adapt and complete it with the measures proposed by Mayer, et al. (1995). 
Table I: Determinants of technology transfer and proxies

\begin{tabular}{|c|c|c|c|c|c|c|}
\hline Determinants & Proxy & Variables & Impact in & $\begin{array}{l}\text { National/ } \\
\text { International } \\
\text { TT }\end{array}$ & Sample & Study \\
\hline \multirow[t]{5}{*}{$\begin{array}{l}\text { Absorptive } \\
\text { capacity }\end{array}$} & $\begin{array}{l}\text { Absorptive } \\
\text { capacity }\end{array}$ & Frequency of R\&D activities & -10 & National level & $\begin{array}{l}\text { Industry-Public } \\
\text { research institu- } \\
\text { tions }\end{array}$ & $\begin{array}{l}\text { Arvanitis and } \\
\text { Woerter (2009) }\end{array}$ \\
\hline & & $\begin{array}{l}\text { Share of employees with } \\
\text { tertiary education intotal } \\
\text { employees (in full-time } \\
\text { equivalents) }\end{array}$ & + & & & \\
\hline & & Investment in R\&D & 0 & $\begin{array}{l}\text { International } \\
\text { level }\end{array}$ & $\begin{array}{l}\text { Country and } \\
\text { firm access to } \\
\text { foreign technol- } \\
\text { ogy }\end{array}$ & $\begin{array}{l}\text { Kneller, et al. } \\
(2010)\end{array}$ \\
\hline & & Provision of formal training & 0 & & & \\
\hline & & Workforce education & 0 & & & \\
\hline \multirow{8}{*}{$\begin{array}{l}\text { Network con- } \\
\text { nectedness }\end{array}$} & & $\begin{array}{l}\text { Importance of government } \\
\text { in accessing knowledge }\end{array}$ & - & & & \\
\hline & & $\begin{array}{l}\text { Importance of universities } \\
\text { and HEls in building inno- } \\
\text { vation }\end{array}$ & - & & & \\
\hline & & $\begin{array}{l}\text { Importance of government } \\
\text { in building innovation }\end{array}$ & - & & & \\
\hline & & $\begin{array}{l}\text { Importance of government } \\
\text { in commercializing innova- } \\
\text { tion }\end{array}$ & & & & \\
\hline & & $\begin{array}{l}\text { Evaluation of closeness of } \\
\text { the interactions at individual } \\
\text { level of the partnership }\end{array}$ & + & & Industry-URC & $\begin{array}{l}\text { Santoro and } \\
\text { Bierly (2006) }\end{array}$ \\
\hline & Social relation & $\begin{array}{l}\text { Intensity of linkages with } \\
\text { managers and/ or profes- } \\
\text { sionals from five types of } \\
\text { organizations }\end{array}$ & + & & $\begin{array}{l}\text { Transfer ac- } \\
\text { tivities among } \\
\text { Canadian } \\
\text { researchers in } \\
\text { occupational } \\
\text { safety and health }\end{array}$ & $\begin{array}{l}\text { Laroche and } \\
\text { Amara }(201 \mathrm{I})\end{array}$ \\
\hline & $\begin{array}{l}\text { Technological } \\
\text { relatedness }\end{array}$ & \begin{tabular}{|l|} 
Impact of accessing the URC \\
expertise
\end{tabular} & & & Industry-URC & \begin{tabular}{|l|} 
Santoro and \\
Bierly (2006) \\
\end{tabular} \\
\hline & & $\begin{array}{l}\text { Impact of accessing the URC } \\
\text { contact network }\end{array}$ & & & & \\
\hline
\end{tabular}

' Mediating institutions: Technology Transfer offices, CTI (Innovation Promotion Agency), SNF/SNFS (Swiss National Science Foundation), EU Framework Programmes, Other European Programmes. Legend: + Positively related; (-) negatively related; (0) no significance 


\begin{tabular}{|c|c|c|c|c|c|c|}
\hline Determinants & Proxy & Variables & $\begin{array}{l}\text { Impact in } \\
\text { TT }\end{array}$ & $\begin{array}{l}\text { National/ } \\
\text { International } \\
\text { TT }\end{array}$ & Sample & Study \\
\hline \multirow[t]{10}{*}{ Trust } & Trust & $\begin{array}{l}\text { Willing to share ideas, } \\
\text { feelings and goals with the } \\
\text { university centre }\end{array}$ & + & National level & Industry-URC & $\begin{array}{l}\text { Gopalakrishnan } \\
\text { and Santoro, } \\
2004\end{array}$ \\
\hline & & $\begin{array}{l}\text { Confidence in the centre's } \\
\text { competence and abilities, } \\
\text { and in its motives and fair- } \\
\text { ness in sharing these abilities }\end{array}$ & + & & & \\
\hline & & $\begin{array}{l}\text { Sharing of a set of princi- } \\
\text { ples that the company finds } \\
\text { acceptable }\end{array}$ & + & & & \\
\hline & & $\begin{array}{l}\text { Firm willingness to share } \\
\text { concerns and problems with } \\
\text { the URC }\end{array}$ & + & & & $\begin{array}{l}\text { Santoro and } \\
\text { Bierly (2006) }\end{array}$ \\
\hline & & $\begin{array}{l}\text { Firm awareness of URC } \\
\text { capability in understanding } \\
\text { their needs }\end{array}$ & + & & & \\
\hline & & $\begin{array}{l}\text { Firm willingness to share } \\
\text { confidences with the URC }\end{array}$ & + & & & \\
\hline & & $\begin{array}{l}\text { Sharing of common business } \\
\text { values }\end{array}$ & + & & & \\
\hline & & $\begin{array}{l}\text { Willing to share ideas, } \\
\text { feelings and goals with the } \\
\text { university centre }\end{array}$ & + & & $\begin{array}{l}\text { Institutionaliza- } \\
\text { tion of knowl- } \\
\text { edge transfer } \\
\text { within Universi- } \\
\text { ty-Industry }\end{array}$ & $\begin{array}{l}\text { Santoro and } \\
\text { Gopalakrishnan, } \\
2000\end{array}$ \\
\hline & & $\begin{array}{l}\text { Confidence in the centre's } \\
\text { competence and abilities, } \\
\text { and in its motives and fair- } \\
\text { ness in sharing these abilities }\end{array}$ & + & & & \\
\hline & & $\begin{array}{l}\text { Sharing of a set of princi- } \\
\text { ples that the company finds } \\
\text { acceptable }\end{array}$ & + & & & \\
\hline \multirow[t]{2}{*}{ Prior experience } & $\begin{array}{l}\text { Prior experience } \\
\text { with partnerships }\end{array}$ & $\begin{array}{l}\text { Relationships between the } \\
\text { company and the URC prior } \\
\text { to the partnership }\end{array}$ & $\begin{array}{l}\text { Control } \\
\text { variable }\end{array}$ & & Industry-URC & $\begin{array}{l}\text { Santoro and } \\
\text { Bierly (2006) }\end{array}$ \\
\hline & & $\begin{array}{l}\text { Number of prior technology } \\
\text { transfer agreements with the } \\
\text { universities }\end{array}$ & - & & $\begin{array}{l}\text { University-In- } \\
\text { dustry }\end{array}$ & $\begin{array}{l}\text { Sherwood and } \\
\text { Covin (2008) }\end{array}$ \\
\hline \multirow[t]{3}{*}{ Size } & Size & Number of employees & $\begin{array}{l}\text { Control } \\
\text { variable }\end{array}$ & & Industry-URC & $\begin{array}{l}\text { Santoro and } \\
\text { Bierly (2006) }\end{array}$ \\
\hline & & & + & & & $\begin{array}{l}\text { Gopalakrishnan } \\
\text { and Santoro } \\
(2004)^{2} \\
\end{array}$ \\
\hline & Sector & $\begin{array}{l}\text { High tech and capital } \\
\text { intense }^{3}\end{array}$ & \begin{tabular}{|l} 
Control \\
variable
\end{tabular} & & & \begin{tabular}{|l} 
Santoro and \\
Bierly (2006)
\end{tabular} \\
\hline
\end{tabular}

${ }^{2}$ The authors use the 7-S Framework as a theoretical basis to identify organizational characteristics that may influence the technology transfer activity. The 7-S Framework is a model of organizational effectiveness developed by Tom Peters and Robert Waterman.The model is based on the assumption that for an organization to be successful, seven internal factors must be aligned (strategy, structure, systems, shared values, skills, style and staff); 3 High tech (biotechnology, electronics, pharmaceuticals, optical equipment, medical laboratories, and research and development services) and capital intense (primary metals, fabricated metal products, industrial machinery, plastic moulding, and ceramics). Legend: + Positively related; (-) negatively related; (0) no significant.

ISSN: 07 I8-2724. (http://www.jotmi.org)

Journal of Technology Management \& Innovation (c) Universidad Alberto Hurtado, Facultad de Economía y Negocios. 
To assess the level of trust between the EEN partners and their clients, the EEN partners and clients were questioned about the extent to which they agree with the statements presented in Table 2, on a seven-point Likert-type scale ( $I=$ strongly disagree, $4=$ neither agree nor disagree, 7 = strongly agree).

It would be expected that companies or other entities that request EEN services would be more prone to successfully transferring technology at an international level if they had already been involved in other partnerships or if they had already established contacts with foreign entities, whether at commercial or technological level.
Concerning the EEN partners, it was assumed that the entities have prior experience in partnerships as the EEN project is in itself an international partnership. Nonetheless, EEN partners were asked to provide an approximate number of international projects related with technology or technology transfer in which the host organization had been involved in the last three years of activity. With the aim of measuring the entity's experience in both national and international partnerships, EEN clients were asked to estimate the number of alliances and the number of technological agreements in which they had been involved in the last three years, both nationally and internationally.

\begin{tabular}{|c|c|}
\hline Proxies: & Source \\
\hline \multicolumn{2}{|l|}{ Trust of EEN Partners(average score of the following items): } \\
\hline \multicolumn{2}{|l|}{ Inter-organizational trust: } \\
\hline Based on past experience, she/he can rely on the EEN with complete confidence. & Zaheer (1998) \\
\hline \multicolumn{2}{|l|}{ My client considered me trustworthy. } \\
\hline \multicolumn{2}{|l|}{ Interpersonal trust: } \\
\hline She/he knows that I look out for her/his interests. & Zaheer (1998) \\
\hline \multicolumn{2}{|l|}{ My performance was above my client's expectations. } \\
\hline \multicolumn{2}{|l|}{ I was committed tothe search fora technological partner. } \\
\hline \multicolumn{2}{|l|}{ She/he was committed tothe search fora technological partner. } \\
\hline \multicolumn{2}{|l|}{ Trust: } \\
\hline $\begin{array}{l}\text { My client is perfectly aware of and has confidence in my competences and abilities as well as my mo- } \\
\text { tives and fairness in sharing these abilities. }\end{array}$ & $\begin{array}{l}\text { Santoro and Bierly } \\
(2006)\end{array}$ \\
\hline \multicolumn{2}{|l|}{ This client is confident tofreely share ideas, feelings, and goals with the EEN. } \\
\hline \multicolumn{2}{|l|}{ We share a set of principles that we both find acceptable. } \\
\hline \multicolumn{2}{|l|}{ Trust of EEN Clients(average score of the following items): } \\
\hline \multicolumn{2}{|l|}{ Inter-organizational trust } \\
\hline Based on past experience, I can rely on my EEN with complete confidence. & Zaheer (1998) \\
\hline \multicolumn{2}{|l|}{ Interpersonal trust (average score of the following items): } \\
\hline She/he is trustworthy. & Zaheer (1998) \\
\hline \multicolumn{2}{|l|}{ I have faith in her/him to look out for my interests. } \\
\hline \multicolumn{2}{|l|}{ Her/his performance was not below my expectations. } \\
\hline \multicolumn{2}{|l|}{ She/he has been committed tothe search for a technological partner. } \\
\hline \multicolumn{2}{|l|}{ Trust (average score of the following items): } \\
\hline I can freely share ideas, feelings, and goals with my EEN. & $\begin{array}{l}\text { Santoro and Bierly } \\
(2006)\end{array}$ \\
\hline \multicolumn{2}{|l|}{ We share a set of principles that I find acceptable. } \\
\hline \multicolumn{2}{|l|}{$\begin{array}{l}\text { I have confidence in her/his competence and abilities as well as her/hismotives and fairness in sharing } \\
\text { these abilities. }\end{array}$} \\
\hline \multicolumn{2}{|l|}{ Level of trust between EEN partner and its client (average score of the following items): } \\
\hline \multicolumn{2}{|l|}{ Trust of EEN Partner } \\
\hline Trust of EEN Clients & \\
\hline
\end{tabular}

Table 2: Measure to estimate the trust relationship between EEN partners and clients

ISSN: 07 I8-2724. (http://www.jotmi.org)

Journal of Technology Management \& Innovation (c) Universidad Alberto Hurtado, Facultad de Economía y Negocios. 
Size and sector were employed as control variables in both questionnaires. Based one earlier studies (Gopalakrishnan and Santoro, 2004; Santoro and Bierly, 2006), size was measured as the entity's number of employees.

The industrial sector is also highlighted as influencing the success of technology transfer (Santoro and Bierly, 2006). For this reason, we classified the EEN members and their clients in accordance with their industrial sector, based on the classification scheme of sector groups. The EEN members are organized into 17 different sector groups. We also measured the sector differentiation by the number of sectors where EEN partners and clients are present in terms of activity.

Due the nature of the agreements, four parties are usually involved: two EEN partners and two EEN clients. Therefore, to explain the international transfer of technology within the Triple Helix, our target population is both the EEN clients and the partners who facilitated that transfer. From the information provided by the EEN, 2I39 technological partnership agreements were signed from 2008 to20II.

Our target population was the EEN partners and their clients that signed technological PAs, which comprised our unit of analysis. The study's starting point was, hence, to build, in cooperation with the EEN officers, a database with all the technological PAs associated to the EEN partners and their clients.

The data gathering process was fraught with difficulties and institutional obstacles. It involved several hierarchical layers within the EEN: the Oporto EEN, the officer responsible for the project management evaluation and monitoring in the $\mathrm{EACl}$, as the network contact point for issues related with PAs, the EACl director, and the unit head of the CIP Network Project. The contacts were made from 24th April to mid-May 2012.

Faced with these difficulties in accessing the required information, we redesigned our approach. We had to give up on obtaining the names and contact details of the EEN clients involved in the PA, and decided to request the contact details of the EEN partners working in technology transfer activities. The survey and information on our study was first sent on 24th May 2012to 60I EEN partners based on the data collected in April. The first mailing allowed us to collect a contact person from $30 \%$ of the EEN partners, as the contacts points on the EEN website did not include this information.
Given the low rate of response and the specificity of the questionnaire, five rounds of emails were sent followed by phone calls. With the contact details provided by the EEN partners, the survey of EEN clients resulted in a population of 35 respondents corresponding to 44 PAs. The second part of our data gathering started on 30th July 2012 with an email to $35 \mathrm{EEN}$ clients. We reinforced the request for collaboration with phone calls and three additional emails (on 6th and 21st August and 3rd September). The response rate was $40 \%$, which corresponds to I 4 surveys regarding 14 partnership agreements.

\section{Results}

It is clear that partners and clients have quite distinct perspectives on the issue of international technology transfer. When asked, with regard to a given PA, about the degree of agreement ( 1 - totally disagree --- 7: totally agree) with the statements "The EEN had helped to develop new technologies that result in new or improved products and services for this client" and "The EEN had played a major role in helping this client transfer and/or acquire new technologies", the mean for EEN partners (5.82I) reveals that they reckon that international technology transfer was quite successful, resulting in new or improved products and services for this client and helping this client transfer and/or acquire new technologies. The viewpoint of the clients is, however, much more disappointing (scoring below 4), revealing that international technology transfer from the clients' perspective was not very successful.

The key hypothesis of our theoretical model of ITT is that certain factors are crucial to the success of international technology transfer within a Triple Helix collaboration. Following the literature review in Section 2, successful international technology transfer is influenced by: human capital $(\mathrm{HC})$, absorptive capacity (AC), network connectedness (NC), trust (Trust), prior experience in international or technological partnership (PE). Moreover, size (Size) and sector diversity (SDIV) also matter (control variables). In algebraic terms, we have (formula I):

where ei is the estimate of the error term.

Consistent with the results of other studies, a positive relationship is expected between international technology transfer and the relevant variables proposed.

$$
\ln I T T_{i}=\hat{\beta}_{1}+\hat{\beta}_{2} H C_{i}+\hat{\beta}_{3} A C_{i}+\hat{\beta}_{4} \text { LnNet }_{i}+\hat{\beta}_{5} L n N C_{i}+\hat{\beta}_{6} \text { LnTrust }_{i}+\hat{\beta}_{7} \operatorname{LnPE}_{i}+\hat{\beta}_{8} \operatorname{LnSize}_{i}+\hat{\beta}_{9} \operatorname{LnSDIV}_{i}+\hat{e}_{i}
$$


The technological PA is an internal document that describes the transfer of technology between two EEN clients from different countries and assisted by two EEN partners. In line with this, the original model proposed encompassed the perspectives of two EEN partners and two EEN clients. The small sample obtained rendered the model as initially proposed unviable. Although perceptions of EEN partners and clients differ, as a trilateral network, the perceptions of EEN partners are likely to reflect the determinants of ITT in a Triple Helix framework. Thus, we used the EEN partners' questionnaires, totalling $7 \mathrm{I}$ responses, as the basis of analysis for this part.

Consistent with the technology transfer definition, we adapted the proxy "Networking dynamics" proposed by Gkikas (20II) and used it as a proxy for the successful international transfer of technology. Henceforth, the dependent variable is a measure taking into account the EEN partners' perception of their role in the clients' process of building and transferring technology. In the same line of reasoning, the proxy "Networking dynamics" is measured by the EEN perception of its role in the clients' access to ideas and information.
To avoid multicollinearity problems in the regression analysis, we use eight models alternating between each of the highly correlated variables: human capital and the proportion of staff involved in ITT with TE; 6. network dynamics and connectedness; prior experience in international partnerships and size. Additionally, the proposed models also capture the effects of the variables that compose the proxies for absorptive capacity and network connectedness.

Table 3 presents the estimation results for the models. The results show that the explanatory variables included in the model tend to significantly explain (for p-value < $10 \%$ ) the success of international technology transfer in a Triple Helix context.

Contrary to our expectations, both human capital and absorptive capacity are negatively correlated with international technology transfer. Awkwardly, the estimations suggest that EEN partners with less human resources dedicated to ITT achieve higher results in terms of PAs, which contradicts Hypothesis I.

\begin{tabular}{|c|c|c|c|c|c|c|c|c|c|}
\hline & Model I & Model 2 & Model 3 & Model 4 & Model 5 & Model 6 & Model 7 & Model 8 & \\
\hline \multirow[t]{3}{*}{ Absorptive capacity (AC) } & $\mathrm{HC}$ & $-0,298^{*}$ & 0,105 & $-0,618^{* * *}$ & $-0,088$ & $-0,746^{\text {*atk }}$ & $-0,091$ & $-0,818^{* w *}$ & $-0,260^{*}$ \\
\hline & $\begin{array}{l}\text { Pro- } \\
\text { portion } \\
\text { of staff } \\
\text { involved in } \\
\text { ITT with } \\
\text { TE }\end{array}$ & & $-0,270^{* *}$ & & $-0,434^{* * *}$ & & $-0,292^{* *}$ & & $-0,388^{*+4}$ \\
\hline & \begin{tabular}{|l} 
Propor- \\
tion of the \\
budget \\
invested in \\
training \\
\end{tabular} & & $1,284^{4 *}$ & & 0,795 & & $0,923^{*}$ & & 0,499 \\
\hline \multirow[t]{2}{*}{ Network Connectedness (NC) } & \begin{tabular}{|l} 
Network \\
Dynamics
\end{tabular} & $0,622^{\text {with }}$ & $0,744^{* *+\alpha}$ & & & $0,522^{k+k}$ & $0,650^{\text {sine }}$ & & \\
\hline & \begin{tabular}{|l|}
$\begin{array}{l}\text { Connect- } \\
\text { edness }\end{array}$ \\
\end{tabular} & & $-0,015$ & & & & $-0,005$ & & \\
\hline Trust (In) & & & $0,757^{*+* 4}$ & $0,778^{*+*}$ & & & $0,679^{* * *+4}$ & $0,717^{\text {s.tat }}$ & \\
\hline $\begin{array}{l}\text { Prior experience in international partner- } \\
\text { ships (PE) (In) }\end{array}$ & 0,004 & 0,021 & $\mid-0,028$ & $-0,016$ & $0,075^{* *}$ & $0,061^{*}$ & & & \\
\hline Size (In) & & & & & $-0,106^{*+*}$ & $-0,072^{*}$ & $-0,056^{* *}$ & $-0,053^{* *}$ & \\
\hline Sector diversity (SDIV) (In) & $-0,048^{* *}$ & 0,043 & $-0,005$ & 0,035 & 0,003 & $0,057^{*}$ & 0,019 & 0,042 & \\
\hline Constant & 1,15 & 0,443 & 0,698 & 0,658 & 1,619 & 0,857 & 1,025 & 0,937 & \\
\hline $\mathrm{N}$ & 71 & 71 & 71 & 71 & 71 & 71 & 71 & 71 & \\
\hline$R^{2}$ adjusted & 0,569 & 0,652 & 0,497 & 0,509 & 0,668 & 0,687 & 0,544 & 0,545 & \\
\hline F-Test (p-value) & $\begin{array}{l}24,09 \\
(0,000)\end{array}$ & $\begin{array}{l}19,752 \\
(0,000)\end{array}$ & $\begin{array}{l}18,270 \\
(0,000)\end{array}$ & $\begin{array}{l}13,098 \\
(0,000)\end{array}$ & $\begin{array}{l}29,197 \\
(0,000)\end{array}$ & $\begin{array}{l}20,249 \\
(0,000)\end{array}$ & $\begin{array}{l}21,896 \\
(0,000)\end{array}$ & $\begin{array}{l}14,989 \\
(0,000)\end{array}$ & \\
\hline
\end{tabular}

Table 3: Regression models for international technology transfer on EEN partners Note: $* * *, * *, *$ denote statistical significance at the $1 \%, 5 \%$ and $10 \%$ test level, respectively.

ISSN: 07 I8-2724. (http://www.jotmi.org)

Journal of Technology Management \& Innovation (c) Universidad Alberto Hurtado, Facultad de Economía y Negocios. 
Regarding absorptive capacity, the regression models where the proxy was scrutinized (Models 2, 4, 5 and 8) reveal surprising patterns. As a whole, absorptive capacity is negatively and significantly related with the success of PAs leading us to reject Hypothesis 2 for this sample. Nonetheless, the variables that constitute the proxy for absorptive capacity, apart from human resources, reflect different trends. On the one hand, the proportion of staff involved in ITT with tertiary education is surprisingly negative and significant. On the other hand, the proportion of the budget invested in training is positive and significant. This means that, on average and ceteris paribus, PAs associated to EEN partners with small teams and higher investments in training tend to reflect more successful ITT.

Globally, network connectedness is positively and highly significant ( $p$-value $<0.00 \mathrm{I}$ in Models I and 5), corroborating Hypothesis 3 , but we can further add that network dynamics is the variable that most contributes to this result. In line with other studies (e.g., Santoro and Bierly, 2006; Arvanitis and Woerter, 2009; Laroche and Amara, 20I I), we found that ITT can be enhanced by network connectedness. A detailed analysis of the variables that constitute the proxy demonstrate that network dynamics, measured by the perception that the EEN partner is a source of ideas and information for its client's TT process, is positively and significantly related with improved ITT. In contrast, the connectedness variable, measured by the number of formal outputs between EEN partner and client, reflects a negative impact on ITT, although it is not significant. This difference in signs and significance can be justified by the impact of more formal or informal contacts in technology transfer. The literature mentions that informal contacts are the most frequent form of transfer (Arvanitis and Woerter, 2009). Indeed, in terms of formality, the exchange of ideas and information is a less formal and tacit process than the creation of documentation.

Similarly, the trust variable is positively related with the success of international technology transfer which supports Hypothesis 4. In the models where trust is included, the corresponding estimated coefficient emerges as positive and highly significant ( $p$-value $<0.00 \mathrm{I}$ ). This result is in line with previous studies (Gopalakrishnan and Santoro, 2004; Santoro and Bierly, 2006) that describe trust as the glue that fosters university and industry alliances.

It is interesting to note that, in the EEN partners sample, trust and network connectedness are significantly correlated $(p<0.10)$ and, as such, trust may be a path to connectedness. This does not imply that trust necessarily leads to network connectedness, but since the latter is measured by the perception that the EEN partner is a source of ideas and information for its client's TT process, enlightenment for the association can be found. A high level of trust be- tween organizations, in our case, between EEN partners and clients, can enrich their interaction, where the client is more willing to share their ideas and requirements (Santoro and Bierly, 2006).

The results for the variable, prior experience in international or technological partnerships are not clear cut. In the models where the trust variable is included (model 3 and $4)$, prior experience has a negative and significant estimate. In models without the trust variable (Models I, 2, 5 and 6), prior experience reveals a positive and significant estimate coefficient in the two most robust models (Models 5 and 6). Hence, given these latter findings, we might consider that the results support Hypothesis 5, where more successful ITT is associated with EEN partners with more experience in international or technology partnerships. This can be justified not only by the accumulation of relevant knowledge regarding the appropriate alliance approaches, but also by the ability to more easily identify collaborative possibilities (Sherwood and Covin, 2008).

Regarding the control variable, size, the models present a negative and significant estimate coefficient with the dependent variable, which indicates that PAs associated with smaller EEN partners are more successful in terms of ITT. This may be interpreted as a hint that 'overcrowding' in an organization is more likely to hinder international technology transfer than to boost it.

For the sector diversity, the results are ambiguous. Nevertheless, in the more robust model (Model 6), the results suggest that sector specialization is an advantage in terms of ITT. Although studying competence specialization in other contexts (absorptive capacity), our result is corroborated by Santoro and Bierly's (2006) study. In an attempt to clarify the definition of absorptive capacity, they mention that, despite the importance of R\&D intensity, only the technological competence of the organization in the specific area of transfer could affect the absorptive capacity. In their research results, Santoro and Bierly (2006) found that not only technological capability (measured by the R\&D intensity), but also technological relatedness (measured by competence in the area of transfer) facilitate knowledge transfer. This can also explain the positive effect of training on absorptive capacity. 


\section{Conclusions}

The empirical results obtained from the analyses of technological partnership agreements signed with EEN support, showed that international technology transfer in Triple Helix collaboration is related with human capital, absorptive capacity, network connectedness, trust and prior experience.

Our first and second hypotheses postulated that human capital and absorptive capacity had a positive impact on the success of ITT under the EEN project. Notwithstanding, the results of our empirical model showed the opposite: both human capital and absorptive capacity emerged as negatively associated with ITT. Thus, apparently, a high proportion of staff with tertiary degrees involved in ITT hampers the successful transfer of technology across borders. The negative impact of absorptive capacity can be explained by the fact that human capital also has a negative tendency; nevertheless, the results for human capital are ambiguous (regression results with positive and negative signs) or without statistical significance. In fact, in a close examination of the absorptive capacity variables, we found that, apart from the human capital, the other two variables have different tendencies. On the one hand, on average, all other factors remaining constant, the higher the proportion of staff with tertiary degrees working with ITT, the lower the success associated to international technology transfer. On the other hand, higher levels of investment in training seem to translate into a higher propensity for successful international technology transfer.Thus, our results underline that high levels of formal schooling per se are not a key determinant of ITT; the critical factor is to have highly educated human resources who receive complementary training in TT-related areas.

Summing up, we conclude that training, international experience, and networks are, overall, the basis for a trilateral network broker of international technology transfer in a Triple Helix environment.
While our empirical operationalization of the Triple Helix framework provides strong support for some ITT determinants that are backed by a solid theoretical background, it nevertheless suffers from methodological limitations. First, given that the PA involves two EEN partners and their respective clients, our focus onjust one side of the PA limits the scope of our model. Collecting data from different participants in the PA could have enhanced the data's and results' richness. Secondly, the focus on determinants which prop the technological partnership agreements in a Triple Helix scheme barred the study of the possible outcomes of the transfer. Future studies should attempt to measure the outcomes of technology transfer. Finally, we must emphasize that this study has merely provided an outline of very complex dynamics. Therefore, further qualitative and quantitative research capturing the determinants of international technology transfer within the Triple Helix is required. 


\section{References}

ARVANITIS, S., Woerter, M. (2009). Firms' transfer strategies with universities and the relationship with firms' innovation performance, Industrial and Corporate Change, 18 (6), 1067-I 106. http://dx.doi.org//0.1093/icc/dtp029

ARVANITIS, S., Kubli, U.,Worter, M. (2005). Determinants of knowledge and technology transfer activities between firms and science institutions in Switzerland: an analysis based on firm data, KOF-Arbeitspapiere/Working Papers I 16, December. http://dx.doi.org//0.2139/ssrn.892575

BESSANT, J., Rush, H. (1995). Building bridges for innovation: the role of consultants in technology transfer, Research Policy, 24, 97 - II4. http://dx.doi.org//0.1016/00487333(93)0075I-e

BOZEMAN, B. (2000). Technology transfer and public policy: a review of research and theory, Research Policy, 29, 627 655. http://dx.doi.org/10.1016/s0048-7333(99)00093-I

COHEN, W. M., Levinthal, D. A. (1990). Absorptive capacity: a new perspective on learning and innovation, Administrative Science Quarterly, 35 (I), 128 -152. http://dx.doi. org/ $10.2307 / 2393553$

DUAN, Y., Nie, W., Coakes, E. (20I0). Identifying key factors affecting transnational knowledge transfer, Information \& Management, 47, 356 - 363. http://dx.doi.org/10.1016/j. im.2010.08.003

EC-CIP (2008). European Commission, Competitiveness and Innovation Framework Programme - Implementation Report 2010, Bruxels: European Commission.

ETZKOWITZ, H. (1998). The norms of entrepreneurial science: cognitive effects of the new university-industry linkages, Research Policy, 27, 823 - 833. http://dx.doi.org/10.1016/ s0048-7333(98)00093-6

ETZKOWITZ, H. (2003). Innovation in innovation: the Triple Helix of University-Industry-Government relations, Social Science Information, 42 (3), 293 - 337. http://dx.doi. org/I 0.1 I 77/05390184030423002

ETZKOWITZ, H., Leydesdorff, L. (1995). The Triple Helix university-industry-government relations: a laboratory for knowledge-based economic development. EASST Review, 14, I4-19.
ETZKOWITZ, H., Leydesdorff, L. (2000). The dynamics of innovation: from National Systems and Mode 2 to a Triple Helix of university-industry-government relations, Research Policy, 29, 109-123. http://dx.doi.org//0.1016/s00487333(99)00055-4

GIBSON, D.V., Smilor, R.W. (199I). Key variables in technology transfer: a field-study based empirical analysis, Journal of Engineering and Technology Management, 8, $287-312$. http://dx.doi.org/I0.1016/0923-4748(9I)900I5-j

GKIKAS, A. (20II). Triple Helix dynamics in peripheral regions: evidence from Wales, in Triple Helix IX International Conference - "Silicon Valley: Global Model or Unique Anomaly?", II-I4 July $201 \mathrm{I}$.

GLASS, A .J., Saggi, K. (2002). Multinational Firms and Technology Transfer, Scandinavian Journal of Economics, 104 (4), 495- 5 I3. http://dx.doi.org/ / 0. I I I / /467-9442.00298

GOPALAKRISHNAN, S., Santoro, M. D. (2004). Distinguishing between knowledge transfer and technology activities: the role of key organizational factors, IEEE Transactions on Engineering Management, 5 I (I), 57 - 69. http://dx.doi. org/I0.I I09/tem.2003.82246I

KELLER,W. (2004). International Technology Diffusion, Journal of Economic Literature, 42, 752 - 782. http://dx.doi. org/I0.1257/002205I042177685

KNELLER, R., Pantea, S., Upward, R. (2010). Does Absorptive capacity affect who benefits from international technology transfer?, in ESTG 2010 Lausanne - Twelfth Annual Conference.

KOHLER, B. M., Rubenstein, A. H., Douds, C. F. (I973). A behavioral study of international technology transfer between the United States and west Germany, Research Policy, 2, 160 - 184. http://dx.doi.org//0.1016/0048-7333(73)9000I-2

LAI,W.- H.(20I I).Willingness-to-engage in technology transfer in industry-university collaborations, Journal of Business Research, 64, 1218 - 1223. http://dx.doi.org/10.1016/j.jbusres.20II.06.026

LAROCHE, E., Amara, N. (20I I). Transfer activities among Canadian researchers: Evidence in occupational safety and health, Safety Science, 49, 406 - 4I5. http://dx.doi. org/10.1016/j.ssci.2010.10.005

LEE, A. H.,Wang,W- M., Lin, T-Y. (20I0).An evaluation framework for technology transfer of new equipment in high technology industry, Technological Forecasting \& Social Change, 77, 135 - 150. http://dx.doi.org/10.1016/j.techfore.2009.06.002 
LEYDESDORFF, L., Etzkowitz, H. (200I).The transformation of university-industry government relations, Electronic Journal of Sociology, 5 (4), at http://www.sociology.org/content/ vol005.004/th.html [13 September 20I4]

LEYDESDORFF, L., Meyer, M. (2003). Triple Helix of university-industry-government relations, Scientometrics, 58 (2), | 9|-203. http://dx.doi.org/I0.1023/A:1026276308287

MADEUF, B. (1984). International technology transfer and international technology payments: definitions, measurements and firm' behavior, Research Policy 13(3), I 25 - 140. http:// dx.doi.org//0.1016/0048-7333(84)9002I-0

MAYER, R. C., Davis, J. H., Schoorman, F.D. (1995).An integrative model of organizational trust, The Academy of Management Review, 20 (3), 709 - 734. http://dx.doi.org//0.5465/ amr.1995.9508080335

PAPAGIANNIDIS, S., Li, F. (2005). Skills brokerage: A new model for business start-ups in the networked economy, European Management Journal, 23 (4), 47I - 482. http://dx.doi. org/I0.10I6/j.emj.2005.06.002

PAPAGIANNIDIS, S., Li, F., Etzkowitz, H. (2009). Entrepreneurial networks: A Triple Helix approach for brokering human and social capital, Journal of International Entrepreneurship, 7 (3), 215 - 235. http://dx.doi.org//0.1007/s I0843009-0038-x

REDDY, N., Zhao, L. (1990). International technology transfer: A review, Research Policy, 10, 285 - 307. http://dx.doi. org/I0.1016/0048-7333(90)900I5-x

SANTORO, M. D, Gopalakrishnan, S. (2000). The institutionalization of knowledge transfer activities within industry-university collaborative ventures, Journal of Engineering and Technology Management, 17, 299 - 319. http://dx.doi. org/I0.1016/s0923-4748(00)00027-8

SANTORO, M. D., Bierly III, P. E. (2006). Facilitators of knowledge transfer in University- Industry Collaborations: A Knowledge-based perspective, IEEE Transactions on Engineering Management, 53 (4), 495 - 507. http://dx.doi. org/I0.I I09/tem.2006.883707

SHERWOOD, A. L., Covin, J. G. (2008). Knowledge acquisition in university-industry alliances: an empirical investigation from a learning theory perspective, Journal of Product Innovation Management, 25 (2), 162 - 179. http://dx.doi. org/I 0. I I I I/j. I540-5885.2008.00292.x
SUNG, T. K., Gibson, D.V., Kang, B- S. (2003). Characteristics of technology transfer in business ventures: the case of Daejeon, Korea, Technological Forecasting \& Social Change, 70, 449 - 466. http://dx.doi.org/I0.1016/s0040-1625(02)003608

TEECE, D. J. (1977). Technology transfer by multinational firms: the resource cost of transferring technological knowhow, The Economic Journal, 87 (346), 242 - 26I. http:// dx.doi.org// $0.2307 / 2232084$

TEIXEIRA,A.A. C., Mota, L. (20I2).A bibliometric portrait of the evolution, scientific roots and influence of the literature on University-Industry links, Scientometrics, 93 (3), 719-743. http:// dx.doi.org/ 0.1007/s I I 192-0 12-0823-5

ZAHEER, A., McEvily, B., Perrone, V. (1998). Does trust matter? Exploring the effects of interorganizational and interpersonal trust on performance, Institute for Operations Research and the Management Sciences, 9 (2), I4I - I59. http:// dx.doi.org/I0.1287/orsc.9.2.14I 